\title{
Study of the Effect of Himreen Dam on the Phytoplankton Diversity in Dyala River, Iraq
}

\author{
Jinan S. Al. Hassany ${ }^{1}$, Zahraa Zahraw ${ }^{1 *}$, Abbas Murtadeh ${ }^{1}$, Hassan Ali $^{2}$, Nidhal Sulaaiman ${ }^{2}$ \\ ${ }^{1}$ Department of Biology, College of Science for Women, Baghdad University, Baghdad, Iraq; ${ }^{2}$ Department of Biology, College of \\ Education Ibn Al-Haitham, Baghdad University, Baghdad, Iraq. \\ Email: *zahraa_zahraw@yahoo.com
}

Received May $23^{\text {rd }}, 2012$; revised June $26^{\text {th }}, 2012$; accepted July $28^{\text {th }}, 2012$

\begin{abstract}
In present study three stations are located on Diyala River has been investigated to study phytoplankton community, the first station was located in Jalawlaa area, second station in Himreen impoundment, while the third station is located after the Himreen Dam in Al-Soddur area, A total 134 taxa of Phytoplankton were identified during the study period, 63, 82 and 84 were identified in stations 1,2 and 3 respectively. The higher density of Phytoplankton observed in station 3 , result ranged between $21.16-23.88 \times 10^{2}$ cell/l during September and October respectively, then station 2 which has density ranged between $18.44-66.188 \times 10^{2}$ cell/l during January and September respectively, while the station 1 has the lowest values during the study comparable to other stations, the result ranged between $5.495-70.62 \times 10^{2}$ cell/1 during January and April respectively. Species Richness Index ranged from $2.9-7.46$ in station 1, $4.08-7.85$ in station 2 and $5.71-8.77$ in station 3. The result revels that the station 3 show to increase in Richness index value in the most of the months comparable to other stations. The Similarity index also has been calculated among the common species of Phytoplankton through the three station by using the Hierarchical cluster analysis is the highest Similarity percentage in reach in $43.5 \%$ for the common species of Phytoplankton between stations 2 and 3.
\end{abstract}

Keywords: Himreen Dam; Impoundment; Phytoplankton; Species Richness; Similarity Index

\section{Introduction}

As it is well known, that Phytoplankton represent the primary producers in aquatic ecosystem, many factor effect their productivity such as light, Temperature, $\mathrm{pH}$ and nutrients, beside its one of the important ecological pyramid component of aquatic ecosystem, and can use as pollution indicators [1]. Several studies were carried on Phytoplankton at different areas of Iraqi lakes [2-6].

Diyala River is one of the main tributaries of the Tigris River. It extend for $386 \mathrm{~km}$ (300 km running in Iraq) from its sources in Iran to drain into the Tigris River south part of Baghdad city, its width range from 100 $500 \mathrm{~m}$, mean river sloop reach to $1.85 \mathrm{~km}$ [7]. Many projects have been made on Diyala River and his branches for water controls and regulating of water distribution on irrigated lands, the containerizing water projects considered one of projects in flood facing and power generations, also it's very important in fish aquaculture. The aim of the study is to investigate on the effect of Himreen Dam on the Qualitative and Quantitative composition of Phytoplankton community of Diyala River.

"Corresponding author.

\section{Materials and Methods}

Three stations were selected in Diyala River, first station is located in jalawlaa area (before Himreen impoundment ), second station in Himreen impoundment, while the third station is located after the Dam in Al-Soddur area (Figure 1), station 1 represents the unregulated part of Diyala River, which is lying before Himreen Dam by $18 \mathrm{~km}$ at north, station 2 represents one of the greater irrigation projects in Iraq which is lying at north eastern of Baghdad city, the height of Himreem Dam is $53 \mathrm{~m}$ and has a discharge about $4050 \mathrm{~m}^{3} / \mathrm{sec}$. the impoundment area is reach to $373 \mathrm{~km}^{2}$ and the highest level for impoundment is $107.5 \mathrm{~m}$. while station 3 (Al-Soddur) represents the regulated part of Diyala River, which is located after Himreem Dam by $10 \mathrm{~km}$ to the south far [8].

Samples were collected from all stations for 12 monthes, using Phytoplankton net $(20 \mu \mathrm{m}$ size $)$ which was lowered beneath the water surface and drewn by a boat slowly for about 15 minutes for qualitative study, the concentrated samples stored with formalin $(4 \%)$ by using a clean polyethylene bottles. One litter was collected from $10 \mathrm{~cm}$ beneath the water surface which was also 


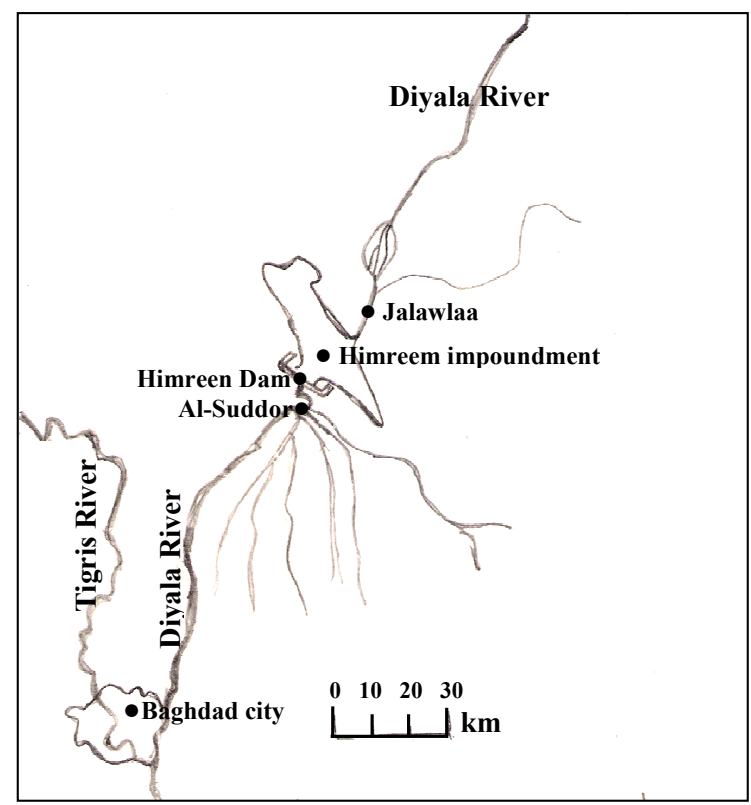

Figure 1. Map of the study area.

stored by using polyethylene bottles for the quantitative study.

In laboratory, Sedimentation technique was used for the cell counted by using Lugol's Iodine Solution, $[9,10]$. the diatoms were cleaned by using nitric acid for clearing the Frustules and counted by microtransct method [11]. Whereas, other algae were counted by Haemacytometer Chamber [12]. Identification of algae species was confirmed by several references [13-16].

\section{Result and Discussion}

One hundred and thirty four taxa of Phytoplankton were identified during the study period. 63,82 and 84 were identified in stations 1, 2 and 3 frequently. The three sta- tions were varied among them in the number of recorded algal species, the highest number of species 37 was observed in station 3 during July, station 2 shows 31 species during June, while station 1 gets the less number of species (10 species) during February (Figure 2).

6 genera represented by greater number of species than other, such as Navicula (11 species), Nitzschia (8), Oscillatoria (7) and (5) for each of Dinobryon, Closterium and Pediastrum. The common numbers of species among all station were 31 species, 10,13, 1, 2, 1 and 4 belong to Chlorophyceae, Bacillariophyceae, Xanthophyceae, Pyrrhophyceae, Euglenophyceae and Cyanophyceae respectively.

A few species were characteristic by their appearance during the study period in all station such as, Osillatoria amphibia, Ceratium hirundinalla, Peridinium cinctum, Aulacoseira granulate, Cyclotella comta, Bacillaria pexillifer, Cymbella affinis, Fragilaria ulna and Closterium acerosum (Table 1) which refer, to the ability of the most of these species for wide tolerance of different environmental factors like temperature, location and environmental conditions, these species prefer to living in natural alkaline water, most of them existing in lotic and lentic ecosystem [17]. Figures 3-5 shows the percentage of species numbers of Phytoplankton that recorded in the stations, Several studies carried out in reservoirs have shown that the main factors influencing phytoplankton composition, density and biomass are water retention time, advection processes, vertical mixture regime, longitudinal and lateral gradients in physical and chemical conditions, as well as the indirect effects of important meteorological factors such as rainfall and wind [18]. In general, the phytoplankton was numerically dominated by Bacillariophyceae observed in the highest percentage in all stations $48 \%, 44 \%$ and $45 \%$ respectively, the domination of diatom is well known phenomenon in

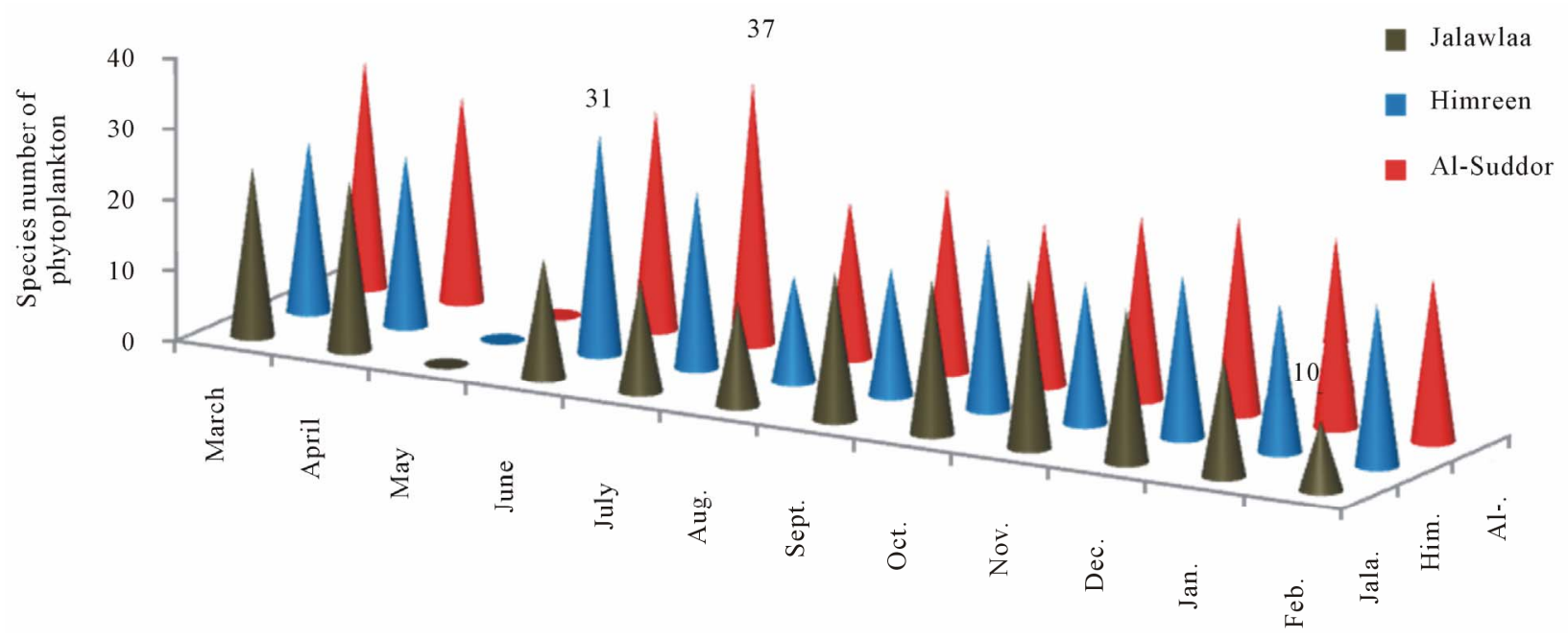

Figure 2. Species number of Phytoplankton that recorded at the study stations. 
Table 1. List of identified algae at the study stations. (+: present, - : absent).

\begin{tabular}{lllll}
\hline Taxa & Stations & 1 & 2 & 3 \\
\hline
\end{tabular}

CYANOPHYCEAE

\begin{tabular}{|c|c|c|c|}
\hline & & & \\
\hline Anabaena sp. & - & + & - \\
\hline Calothrix sp & + & + & - \\
\hline C. braunii Bront \& flahant & - & - & + \\
\hline C. fusca (Kütz.) Bront \& flahant & - & - & + \\
\hline Chroococcus sp. & - & - & + \\
\hline C. turgidus (Kütz.) Nägeli & - & - & + \\
\hline Coelosphaerium kuetzingianum Naegli & - & + & - \\
\hline Dactylococcpsis fascicularis lemmermann & - & - & + \\
\hline Coelosphaerium aponina Kützing & - & - & + \\
\hline Lyngbya aeruginosa-coerulea (Kütz.) Gomont & - & + & - \\
\hline Merismopedia glauca (Eher.) Nägeli & - & + & + \\
\hline M. punctata Meyen & + & + & - \\
\hline Microcystis aeruginosa Kützing & + & + & + \\
\hline Oscillatoria sp. & - & - & + \\
\hline O. agardhii Gomont & - & + & - \\
\hline O. amoena (Kütz.) Gomont & - & + & + \\
\hline O. amphibia Agardh & + & + & + \\
\hline O. princeps Vaucher & + & + & + \\
\hline O. rubescens Decandoile & - & - & + \\
\hline O. tenuis Agardh & + & + & + \\
\hline Phormidium sp. & + & + & - \\
\hline P. tenue (Menegh.) Gomont & + & - & - \\
\hline Scytonema sp. & - & + & + \\
\hline Spirulina sp. & + & + & - \\
\hline EUGLENOPHYCEAE & & & \\
\hline Euglena gracilis Kelebs & + & + & + \\
\hline E. oxyuri schmardad & + & + & + \\
\hline Phacus caudataus Huebure & + & - & + \\
\hline PYRRHOPHYCEAE & & & \\
\hline Ceratium hirundinella (Müll.) Dujardin & + & + & + \\
\hline glenodinium gymnodiinium Penard & - & + & - \\
\hline Peridinium cinctum (Muell.) Ehrenberg & + & + & + \\
\hline p. cinctum var. tubersum (Meunier) Lindeman & - & - & + \\
\hline p. pusillum (penard) Lemmermann & - & - & + \\
\hline
\end{tabular}

\section{Continued}

\begin{tabular}{ccccc}
\hline Dinobryon sp. & - & + & - \\
D. cylindricum Imhof & - & + & + \\
D. divergens Imhof & + & + & + \\
D. divergens var. tuberosunm & - & + & - \\
Dinobryon sertularia Ehrenberg & - & - & +
\end{tabular}

RHODOPHYCEAE

Composogon coeruleus (Balbis) Mont

BACILARIOPHYCEAE

Centrales

Aulacoseira granulate (Ehr.) Ralf

A. italic (Ehr.) Simonsen

A. varians Agardh

Cosinodiscus kuetzingii A. Scmidt

Cosinodiscus lacustris Grunow

Cyclotella comta (Eher.) Kützing

C. Kuetzingiana Thwaites

C. ocellata Pant

Pennales

Achanthes sp.

A. lanceolata Brébission

A. minutissima Kützing

Amphora sp.

A. cymbifera Gregory

A. ovalis Kützing

A. robusta Gregory

Anomoeoneis sp.

Anomoeoneis exilis (Kütz.) Cleve

Bacillaria paxillifer (Müll.) Hendy

Caloneis sp.

Cocconeis pediculus Ehrenberg

C. placentula Ehrenberg

Cymatoptopleura ellipitca (Brèb.) Smith

C. solea (Brèb) Smith

Cymbella affinis Kützing

C. cistula (Hemp.) Grunow

C. navicliformis

C. tumida (Bréb.) V. Heurck 


\section{Continued}

\begin{tabular}{|c|c|c|c|}
\hline Diatoma sp. & + & - & - \\
\hline D. elongatum (Lyng.) Agardh & - & + & + \\
\hline Diatoma vulgare Bory & + & + & + \\
\hline Fragilaria ulna (Nitz.) Ehrenberg & + & + & + \\
\hline F. capucina Desmazieres & + & - & - \\
\hline Gomphonema sp. & - & - & + \\
\hline G. constrictum Ehrenberg & - & + & - \\
\hline G. lanceolatum Ehrenberg & - & - & + \\
\hline Gyrosigma sp. & + & + & + \\
\hline Navicula. $\mathrm{sp}$. & + & + & + \\
\hline N. cryptocephala Kützing & + & + & + \\
\hline N. cuspidata Kützing & - & - & + \\
\hline N. fusca Greg. & - & - & + \\
\hline N. fusiform Grunow & + & - & - \\
\hline N. iridis Her. cleve & + & - & - \\
\hline N. pusilla W. Smith & - & + & - \\
\hline$N$. radiosa Kützing & - & - & + \\
\hline N. rhyncocephala Kützing & + & - & + \\
\hline N. virids Kützing & - & + & + \\
\hline N. viridula (Kütz.) Ehrenberg & + & + & - \\
\hline Neidium sp. & + & - & - \\
\hline Nitzschia fasciculata Grunow & - & + & - \\
\hline N. granulate Grunow & - & + & - \\
\hline N. longissima (Breb.) Ralfs & - & + & - \\
\hline N. palea Kützing & + & + & + \\
\hline N. sigma (Kütz) W. Smith & - & + & + \\
\hline N. sigmoidea (Ehr.) W. Smith & - & + & + \\
\hline N. vermicularis (Kütz.) Hantzsch & + & + & + \\
\hline N. hippocampus W. Smith & - & - & + \\
\hline Stauroneis sp. & - & - & + \\
\hline Surirella sp. & + & - & - \\
\hline Surirella capronii Brèbisson & - & - & + \\
\hline S. ovalis Brèbisson & - & + & + \\
\hline S. robusta Ehrenberg & - & + & - \\
\hline Tabellaria sp. & + & + & + \\
\hline \multicolumn{4}{|l|}{ CHLOROPHYCEAE } \\
\hline Ankistrodesmus falcatus (Cord.) Ralfs & + & - & - \\
\hline
\end{tabular}

\section{Continued}

\begin{tabular}{|c|c|c|c|}
\hline Botryococcus braunii Kützing & - & + & - \\
\hline Bulbochaete angulosa Wittrock \& Iundell & + & - & + \\
\hline Chlamydomonas polypyrcnoideum Prescot & - & + & - \\
\hline Cladophora sp. & + & - & - \\
\hline Closteriopsis longissima Wands Worth & + & - & - \\
\hline Closterium sp. & + & - & - \\
\hline C. acerosum (Schrank) Ehrenberg & + & + & + \\
\hline C. leibleinii Kützing & - & + & + \\
\hline C. moniliferum (Bory) Ehrenberg & - & + & - \\
\hline C. setaceum Ehrenberg & - & - & + \\
\hline Coelastrum microporum Nägeli & + & + & + \\
\hline C. reticulum (Dang.) Senn & - & + & - \\
\hline Cosmarium sp. & - & - & + \\
\hline C. bioculatum Brébisson & + & - & - \\
\hline C. granatum Brébisson & + & - & - \\
\hline C. punctulatum Brébisson & - & + & + \\
\hline Dictyosphaerium pulchellum Wood & + & + & + \\
\hline Oedogonium sp. & + & - & + \\
\hline Oocystis borgei Snow & + & + & + \\
\hline Pandorina morum (Muell.) Bory & - & + & - \\
\hline Pediastrum boryanum (Turp.) Meneghini & - & + & - \\
\hline P. duplex Meyen & + & + & + \\
\hline P. simplex var. duodenarium (Bailey) Rabenhorst & + & + & + \\
\hline p. tetras (Her.) Ralfs & - & + & - \\
\hline Scenedsmus bijuga (Turp.) Lagerheim & + & + & + \\
\hline S. dimorphus (Trup.) Kützing & - & - & + \\
\hline S. quadricauda (Turp.) Brébisson & - & + & - \\
\hline Sphaerocystis schroeteris Chodat & - & + & - \\
\hline Spirogyra sp. & + & - & + \\
\hline Staurastum cingulum (west \& West) Smith & + & + & + \\
\hline S. natans & + & + & + \\
\hline Tetraëdron minimum (A. Braun) Hansgirg & - & + & + \\
\hline Green cells & - & + & - \\
\hline
\end{tabular}

Iraqi water and recorded by many researcher [19-21], which may be due to the ability of diatom to grow and reproduce in wide range of environmental changes such as temperature, light intensity, nutrients availability and salinity, the composition of algal community quickly 


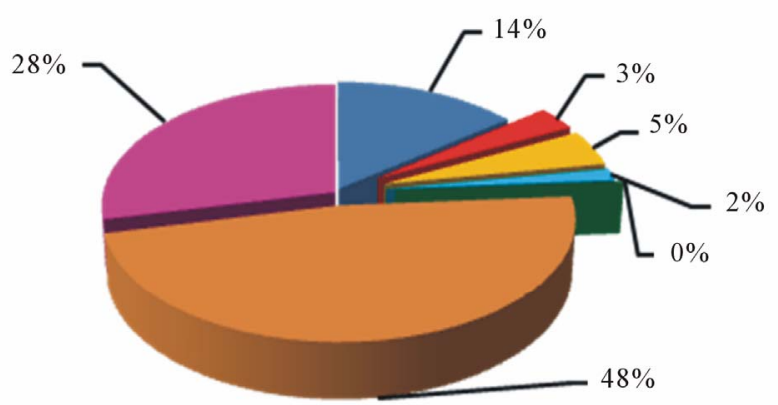

Cyanophyceae

Dinophyceae

Rhodophyceae

Figure 3. The percentage of species numbers of Phytoplankton that recorded in Jalawlaa.

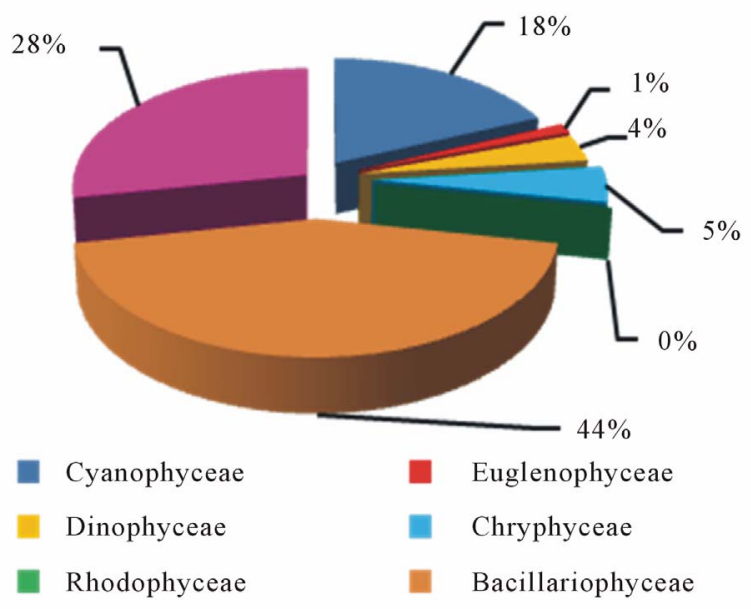

Figure 4. The percentage of species numbers of Phytoplankton that recorded in Himreen Impoundment.

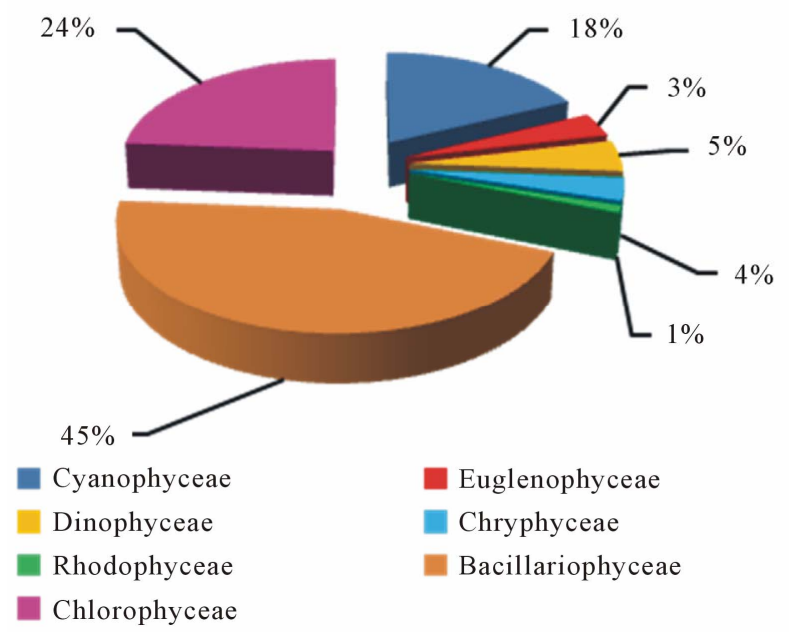

Figure 5. The percentage of species numbers of Phytoplankton that recorded in Al-Suddor. respond to changes in physical, chemical and biological factors [22]. While Chlorophyceae were the subdominant group after diatoms in the percentage of species numbers followed by Cyanophyceae were reached to $18 \%, 14 \%$, $18 \%$ of the phytoplankton composition in three station respectively, this is the regime in the Iraqi water where the Chlorophyceae prevailing the Cyanophyceae in water, which refer, to species exiguities of Cyanophyceae in Tigris and Euphrates basin $[23,24]$.

The higher density of Phytoplankton observed in station 3, result ranged between $21.16-23.88 \times 10^{2} \mathrm{cell} / 1$ during September and October frequently, followed station 2 by density ranged between $18.44-66.188 \times 10^{2}$ cell/1 during January and September respectively, while the station 1 has the lowest values during the study comparable with other stations, the result ranged between $5.495-70.62 \times 10^{2}$ cell/1 during January and April frequently (Figure 6).

Quantitative Counts showed clear seasonal variation in phytoplankton cell numbers with maxima during spring and early autumn. This phenomenon was observed by other authors in Iraq such as [25], in Himreen lake, [6] in Qadisia Lake and [26] in Habbaniya Lake. This increasing may be caused by light intensity and the long photo period [27], raising of temperature, decomposition of organic matter and the assemblage of nutrients material that are important for these organisms [28]. Impoundment may influence the plankton population of a body of water in a number of ways. Reduction of the rate of flow of a stream will allow the sparse plankton already present to multiply before it is swept away. Often a large plankton population develops when the reservoir is filling and there is little outflow [29] Even after the reservoir is full and outflow becomes substantial, a fairly large plankton population may persist. Various authors have attempted to difine the conditions of flow under which the transformation of a stream ecosystem to a lake ecosystem may occur [30]. Russian scientists [31] suggest simpler criteria; in Russian reservoirs a lacustrine plankton population develops if the rate of the flow is less than $0.2 \mathrm{~m} \cdot \mathrm{sec}^{-1}$. It seems unlikely that any simple criterion is universally applicable. Typically many reservoir contain regions of fairly raped flow where the plankton population will be small and other region of slack water where considerable population may develop [30]. Basically, increasing of algal density refer to diatom which comprises $64 \%, 40 \%$ and $53 \%$ of total number of Phytoplankton in the three stations frequently (Figures 7-9). The dominated of diatom in Iraqi water was recorded by many researcher [1921]. Higher percentage of Chlorophyceae $20 \%$ of the total numbers of phytoplankton were recorded at station 3 and $18 \%, 15 \%$ in station 1 and 2 respectively. For dinophyceae our observations show that cell abundance increased when the current increasing which for grow 


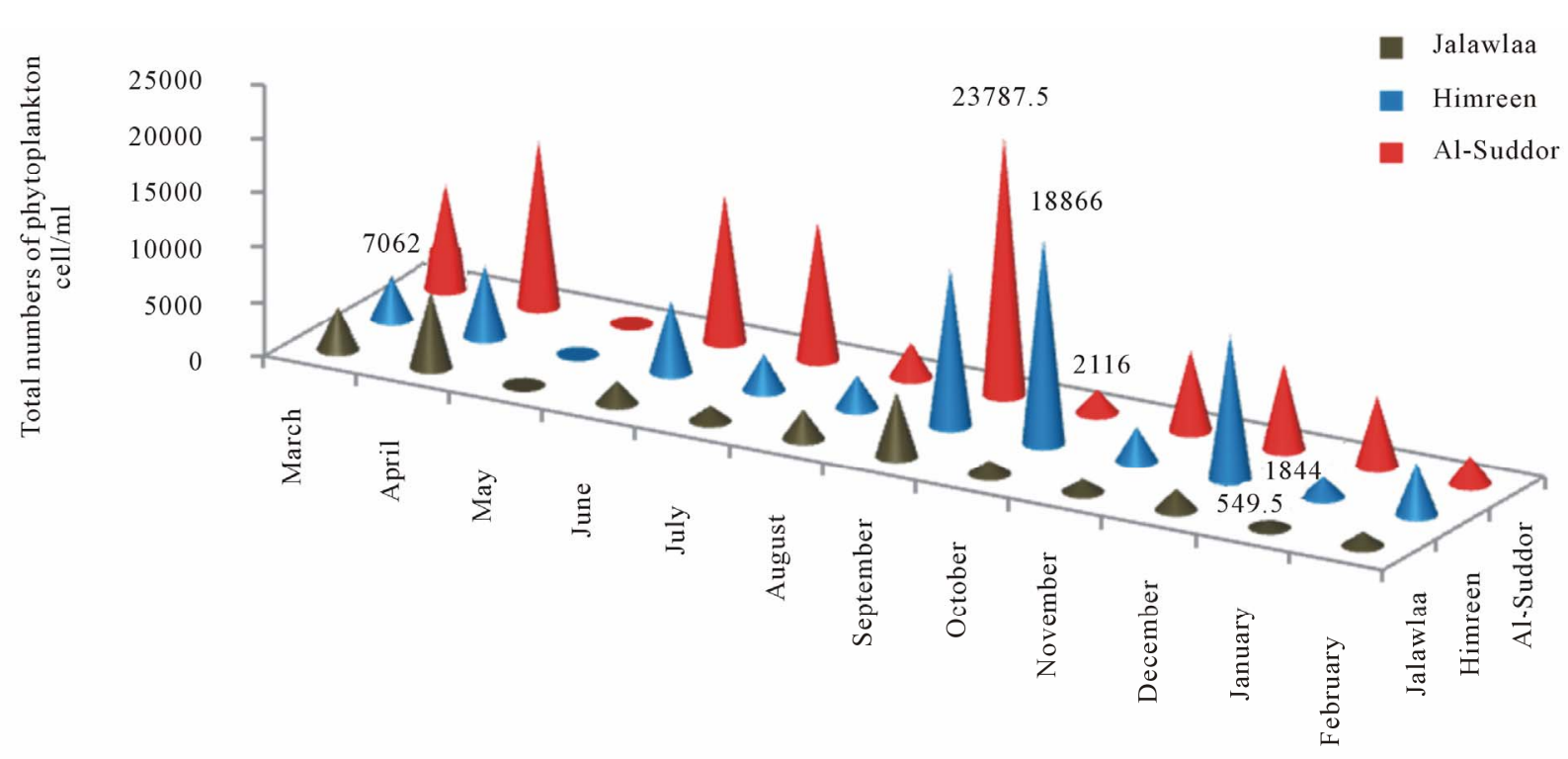

Figure 6. Total cells number of Phytoplankton that recorded at the study stations.

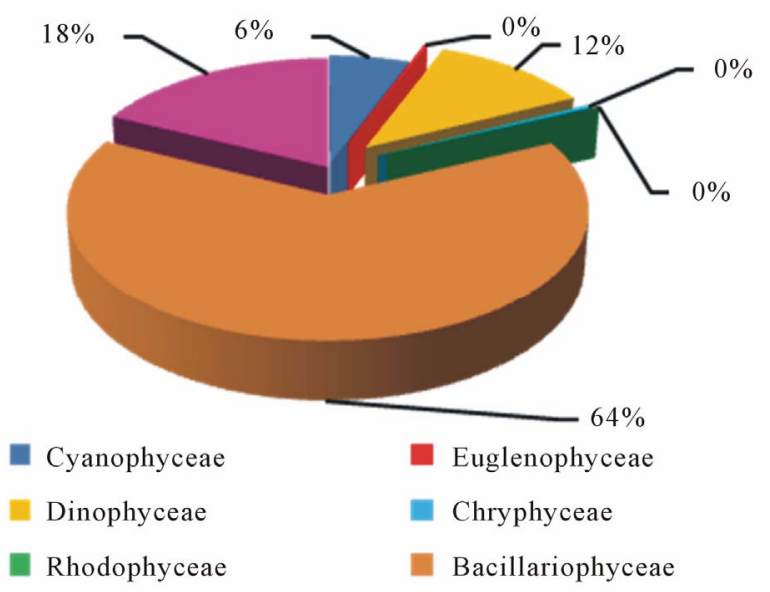

Figure 7. The percentage of total numbers of Phytoplankton that recorded in Jalawlaa.

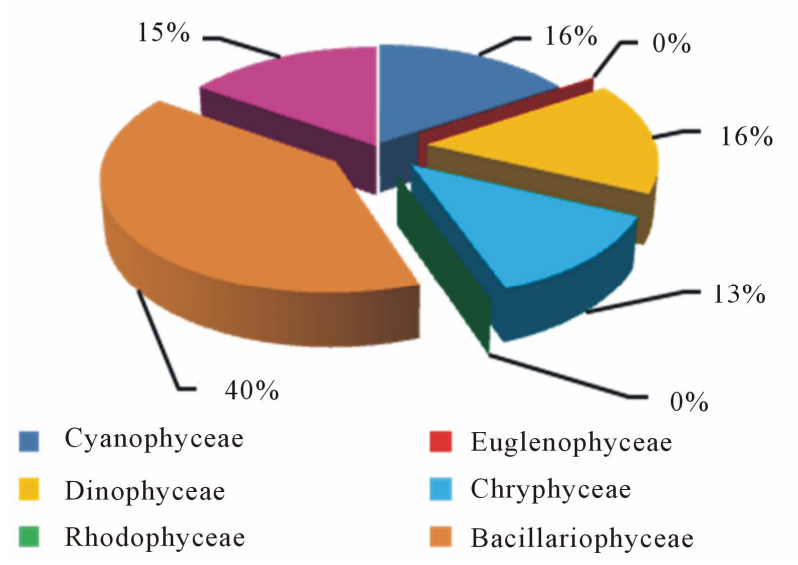

Figure 8. The percentage of total numbers of Phytoplankton that recorded in Himreen Impoundment.

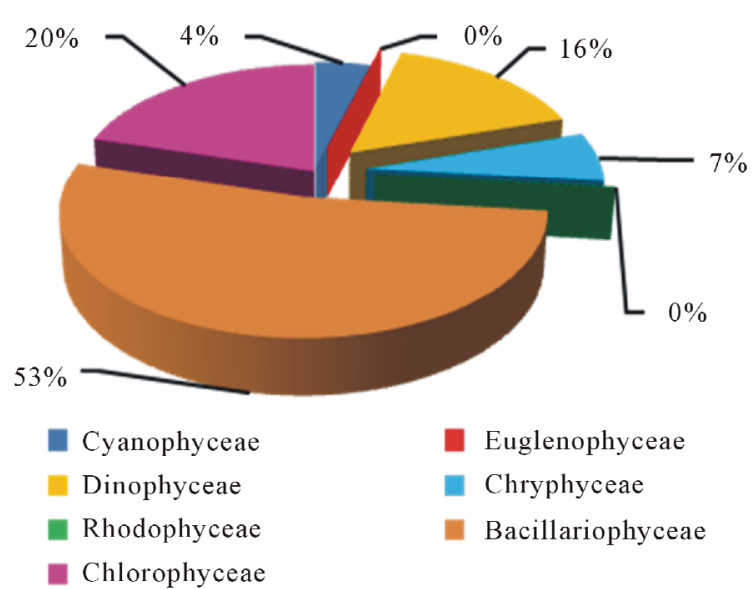

Figure 9. The percentage of total numbers of Phytoplankton that recorded in Al-Suddor.

and reproduction of these group, so we see increasing in Dinophyceae density in both station 1 and 3 when the current is high but in station 2 which exhibit lake ecosystem, we found decreasing in Dinophyceae density [30]. Higher abundance of Cyanophyceae observed in upper part, then becomes degrease in the impoundment and after the dam where reached to $16 \%, 6 \%, 4 \%$ of the phytoplankton numerical abundance respectively, The relative low abundance of this group in reservoirs and after the dam can be attributed to the predominant oligotrophic conditions of the reservoirs and to the prevalent low retention time. In lake volta, blue green algae predominated at first in the upper and diatom in the more lake-like lower part. Subsequently diatoms have established themselves more widely throughout the reservoir [32]. Above result illustrated the increasing of density 
always occur in station 3, which reflect the role of regulated site in increasing of population density clearly, therefore we find that population density in regulated site are higher than unregulated site in most of the months which may be relate to suitability of natural bottom and its settling, lower turbidity, aeration conditions and availability of food resources [33]. So it seems that's river regulation has positive effect in increasing of species numbers when we compare between the regulated site and unregulated site.

\section{Species Richness Index}

Species Richness is the primary measurement for community and local diversity, the index describe the species composition and the range of its diffusion, and represent, the identified taxonomic units inside the sample and its diversity, the measure of taxonomic unit richness covers the changes in studied biological community [34], the result of Index ranged from $2.9-7.46$ in station1, 4.08 7.85 in station 2 and $5.71-8.77$ in station 3. The result revels that the station 3 shows increase in Richness index value in most of the months comparable to other stations (Figure 10) This demonstrated the effect of dam in allowing the appearance of new species, the increasing of index of taxonomic units Richness correlated to increase of integrity of biological community and the places where they live in [34].

\section{Jaccard Similarity Index}

It has been calculated the Similarity percentage among the common species of Phytoplankton through the three station by using the Hierarchical cluster analysis, the resulting Dendrogram (Figure 11) show the strength of species similarity between studied stations by using the species list, Table 2 illustrated the species Similarity percentage among stations during study period, when the highest Similarity percentage reach $43.5 \%$ for the common species of Phytoplankton between stations 2 and 3, which refer to drift of organisms into the river during the lakes and pools wash processing, and the increasing of taxonomic order in regulated sites may return to its drift from surrounded areas [34] or the persistence ability of

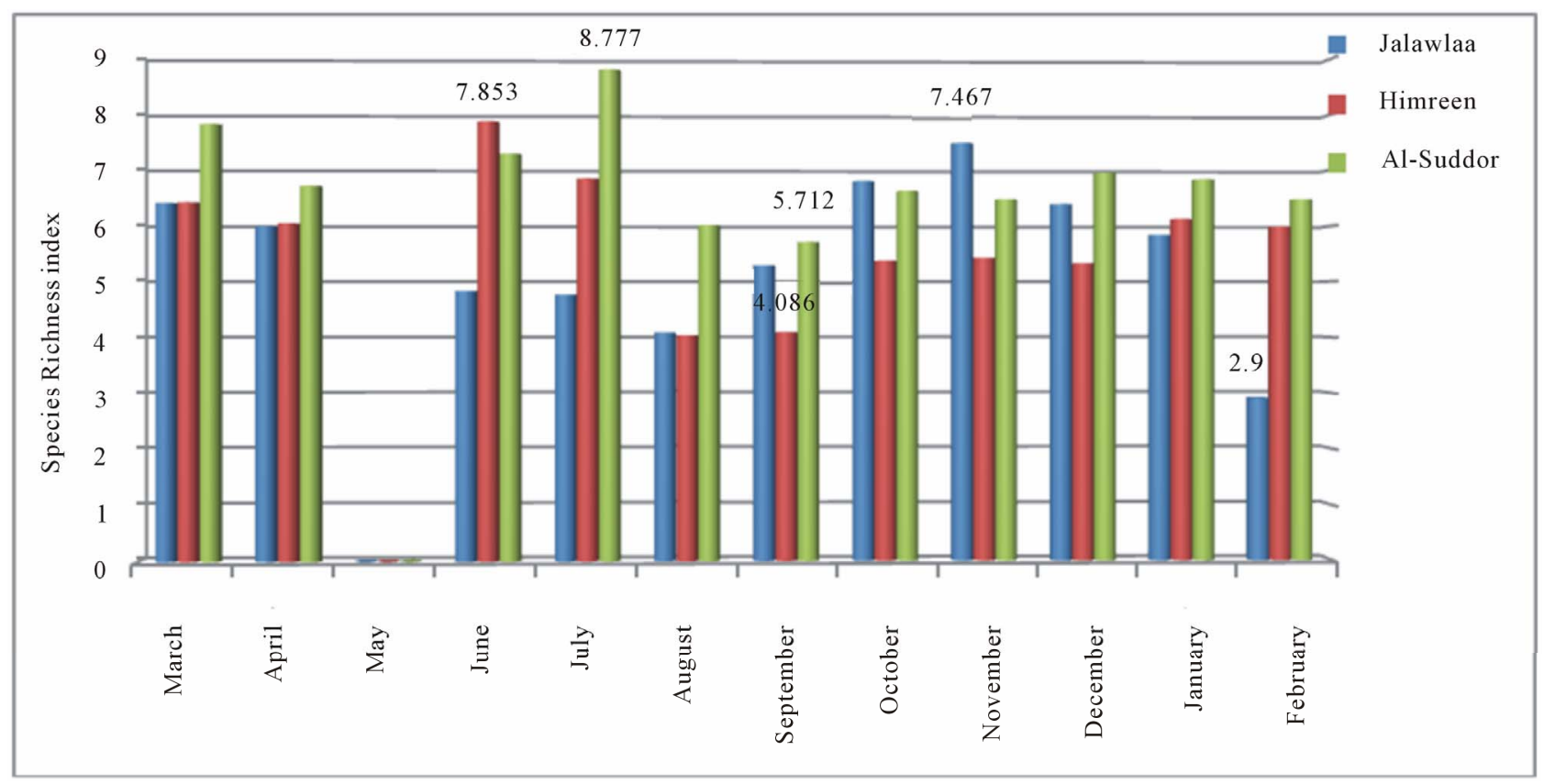

Figure 10. Species Richness index at the study stations.

Table 2. The Similarity percentage between Phytoplankton species at the study stations according to Jaccard Index.

\begin{tabular}{cccc}
\hline \multicolumn{3}{c}{ Jaccard measure } & \\
\hline Site & Jalawlaa & Himreen & Suddor \\
\hline Jalawlaa & - & 34.3 & 36.4 \\
Hireen & 34.3 & - & 43.5 \\
Suddor & 36.4 & 43.5 & - \\
\hline
\end{tabular}




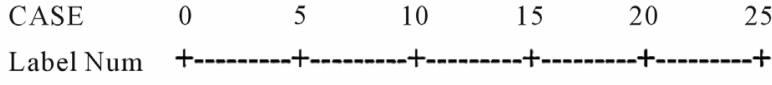

$\begin{array}{ll}\text { Himreen } 2 & \\ \text { Al-Suddor } 3 & \end{array}$

Jalawlaa 1

$(35.4)$

Figure 11. Show the strength of species similarity between Phytoplankton in the study stations according to Jaccard Index.

many species that have positive relation with discharge, however species numbers are more in regulated part of river [35].

\section{REFERENCES}

[1] B. A. Whitton, "River Ecology," Black Well Scientific Publication, Oxford, 1975.

[2] R. A. Hadi, A. M. Ismail and A. H. Talib, "Check List of the Algae in Dyala River, Iraq," Um.Salama Science Journal, Vol. 6, No. 2, 2000, pp. 329-345.

[3] A. A. Al-Lami, A. W. Sabri, T. I. Kassim and K. A. Rasheed, "Phytoplankton of Samarra Reservoir, Iraq," Acta Hydrobiologia, Vol. 38, No. 3-4, 1996, pp. 77-86.

[4] T. I. Kassim, H. A. Al-Saadi, S. K. Salman and R. K. Farhan, "Species Composition and Seasonal Variation of Phytoplankton in Habbaniya Lake, Iraq," Iraq Journal of Biology, Vol. 1, No. 1, 2001, pp. 23-34.

[5] H. A. Al-Saadi, F. M. Hassan and F. M. Alkam, "Phytoplankton and Related Nutrients in Sawa Lake, Iraq," Journal of Dohuk University, Vol. 11, No. 1, 2008, pp. 67-76.

[6] T. I. Kassim, H. A. Al-Saadi, A. A. Al-Lami and R. K. Farhan, "Spatial and Seasonal Variations of Phytoplankton in Qadisia Lake, Iraq," The Science Journal of Iraq Atomic Energy Commission, Vol. 1, 1999, pp. 99-111.

[7] N. A. Al-Ansari, "Hemreen Reservoir, Geological and Hydrological Investigation," Journal of Water Resources, Special Publication No. 2, 1987.

[8] H. A. A. Saadalla, "Ecological Study on the Effect of Himreen Impoundment on the Benthic and plankton Invertebrates of River Diyala," Ph.D. Thesis, University of Baghdad, Baghdad, 1988, $254 \mathrm{p}$.

[9] R. A. M. Hadi, "Algal Studies of the River USK," Ph.D. Thesis, University of Cardiff, College Cardiff, 1981, 364 p.

[10] J. E. Furet and K. Benson-Evans, "An Evaluation of the Time Required to Obtain Complete Sedimentation of Fixed Algal Particles Prior to Enumeration," Journal of British Phycological, Vol. 17, No. 3, 1982, pp. 253-258.

[11] R. Patrick and C. W. Reimer, "The Diatom of the United States," Vol. 2, Part 1, Philadelphia, Monograph 13, 1975, 213 p.

[12] M. R. Martinez, R. P. Chakroff and J. B. Pantastica, "Note on Direct Phytoplankton Counting Technique Using the Haemocytometer," Philippine Agricultural, Vol.
59, 1975, pp. 1-12.

[13] H. Germain, "Flora des Diatomees. Diatomophyceae eau Douces et Saumatres du Massif Armoricion et des Contrees Voisines d'Europe Occindentale," Sciete Nouvelle des Edition, Boubee, Paris, 1981.

[14] F. Hustedt, "The Pennate Diatoms. A Translation of Hustedt'S, Die Kieslalgen," Strauss and Cramer Gmbh, Germany, 1959, 918 p.

[15] T. V. Desikachary, "Cyanophyta, Indian Council of Agricultural Research," New Delhi, 1959, 686 p.

[16] G. W. Prescott, "Algae of the Western Great Lakes Area," William, C. Brown Co., Publ. Dubuque, Iowa, 1982, 977 p.

[17] R. L. Lowe, "Environmental Requirements and Pollution Tolerance of Freshwater Diatoms," US Environmental Protection Agency, Cincinnati, 1974, 334 p.

[18] L. Campbell, R. J. Olson, H. M. Sosik, A. Abraham, D. W. Henrichs , C. J. Hyatt and E. J. Buskey, "First Harmful Dinophysis (Dinophyceae, Dinophysiales) Bloom In The U.S. Is Revealed By Automated Imaging Flow Cytometry," Journal of Phycology, Vol. 46, No. 1, 2010, pp. 66-75. doi:10.1111/j.1529-8817.2009.00791.x

[19] A. A. Al-Lami, T. I. Kassim and S. K. Salman, "Phytoplankton of Tigris River, Iraq," 1st National Scientific Conference in Environmental Pollution and Means of Protection, Baghdad, 5-6 November 2000, pp. 10-20.

[20] H. A. Al-Saadi and A. M. Ismail, "Comparison of Phytoplankton Composition in Artifcial Lake and Tigris River, Middle of Iraq," Journal of College Education for Women, University of Baghdad, Vol. 12, No. 1, 2001, pp. 105112.

[21] F. M. Hassan, R. A. A. Hadi, T. I. Kassim and J. S. Al-Hassany, "Systematic Study of Epiphytic Algal after Restoration of Al-Hawizah Marshes, Southern of Iraq," International Journal of Aquatic Science, Vol. 3, No. 1, 2012, pp. 37-57.

[22] M. Kasim and H. Mukai, "Contribution of Benthic and Epiphytic Diatoms to Clam and Oyster Production in the Akkeshi-Ko Estuary," Journal of Oceanography, Vol. 62, 2006, pp. 267-281. doi:10.1007/s10872-006-0051-9

[23] J. F. Talling, "Euphrates and Tigris, Mesopotamian Ecology and Desting," Vol. 38, The Hyge-Boston-London. 1980, pp. 63-86.

[24] B. A. Al-Nimma, "A Study on the Limnology of the Tigris and Euphrates Rivers," M.Sc. Thesis, University of Salahulddin, 1982.

[25] S. K. Salman, T. I. Kassim and H. A. Al-Saadi, "Seasonal and Spatial Variations of Phytoplankton in Hemren lake, Iraq," Journal of College of Education for Women, Vol. 13, No. 3, 2002, pp. 521-526.

[26] T. I. Kassim, H. A. Al-Saadi and R. K. Farhan, "Vertical Distribution of Phytoplankton in Habbaniya Lake, Iraq," Marsh Bulletin, Vol. 1, No. 1, 2006, pp. 19-31.

[27] A. A. M. Al-tamimi, "Using Algae as Bioindicators for Organic Pollution in the Lower Part of Diyala River," Ph.D. Thesis, Baghdad University, Baghdad, 2006, 208 p.

[28] C. G. Peterson and R. J. Stevenson, "Seasonality in River 
Phytoplankton: Multivariate Analyses of Data from the Ohio River and Six Kentucky Tributaries," Hydrobiologia, Vol. 182, No. 2, 1989, pp. 99-114. doi:10.1007/BF00006036

[29] A. J. Mclachlan, "Development of Some Lake Ecosystem in Tropical Africa, with Special Reference to the Invertebrates," Biological Reviews, Vol. 49, 1974, pp. 365-396.

[30] R. M. Baxter, "Environmental Effects of Dams and Impoundments" Annual Review of Ecology and Systematic, Vol. 8, 1977, pp. 255-283.

doi:10.1146/annurev.es.08.110177.001351

[31] Y. Y. Tseeb, "On Certian Regulation Features Associated with the Formation of the Hydrobiological Regime in the Kakhovsk Reservoir," Kakhovsk Reservoir. Tr. Zon. Sov. Tipol. Biol. Rib. Ispol. Vunt. Vod. Younzh. Zony. SSR. 30, 1962, pp. 204-210 (In Russian. Natl. Lend. Libr. Sci. Tech. Translation RTS 2936).

[32] S. Biswas, "The Volta Lake; Some Ecological Observa- tions on the Phytoplankton," Internationale Vereinigung für Theoretische und Angewandte Limnologie: Verhandlungen, Vol. 17, 1969, pp. 259-272.

[33] A. Compin and R. Cereghion, "Spatial Patterns of Macroinverte-Brate Physical Variables Land-Cover in Southwestern France," Landscape Ecology, Vol. 22, No. 8, 2007, pp. 1215-1225. doi:10.1007/s10980-007-9101-y

[34] J. S. Levinton, "Marine Biology. Function, Biodiversity, Ecology," 2nd Edition, Oxford University Press, Inc., Oxford, 2001.

[35] E. B. Kratzer, K. J. Jackon, D. B. Arscott, A.K. Aufdenkampe, C. L. Dow, L. A. Kaplan, J. D. Newbold and B. W. Sweeney, "Macroinvertebrate Distribution in Relation to Land Use and Water Chemistry in New York City Drinking-Water-Supply Watersheds," Journal of North American Benthological Society, Vol. 25, No. 4, 2006, pp. 954-976. 